\title{
Editorial
}

\section{Developing Democracy: Conversations on Democratic Governance in International, European and Comparative Law}

\author{
Clara Rauchegger* and Anika Seemann**
}

Conference Conveners

This Issue results from the Fourth Annual Conference of the Cambridge Journal of International and Comparative Law, which was held at the University of Cambridge on 8 and 9 May 2015.

The Conference theme, 'Developing Democracy: Conversations on Democratic Governance in International, European and Comparative Law', was chosen to promote an international exchange on current challenges to democracy. The Conference theme understood democracy as a work in progress, both at a normative and at a practical level. By placing the concept of 'democracy' in the context of 'development', we invited speakers to (re-)define its meaning, to confront political realities with democratic ideals and to explore promising solutions to the challenges they identified.

In line with the international and comparative law focus of the Journal, scholars from several transnational fields of legal research came together in Cambridge for a joint exploration of democratic governance from various perspectives. The Conference thus brought together debates that tend to be held separately. We were heartened to find that there was much demand for this platform of exchange. Our call for papers attracted responses from all corners of the globe and from a variety of fields of legal research. We had to make difficult choices as more than 200 abstracts were submitted.

The final Conference programme featured speakers from five continents, including early career researchers and established academics, as well as legal practitioners. The Conference papers, grouped into ten panels, were complemented by three highly insightful keynote speeches, delivered by Dame Rosalyn Higgins DBE QC, former President of the International Court of Justice, Judge James Crawford AC SC FBA of the

\footnotetext{
* PhD Candidate, Trinity Hall, University of Cambridge (UK), DOC Fellow of the Austrian Academy of Sciences.

** PhD Candidate, Corpus Christi College, University of Cambridge (UK).
} 
International Court of Justice, and Judge Christopher Vajda of the Court of Justice of the European Union. These presentations, in conjunction with a book launch-Dr Freya Baetens introduced the co-edited book Sovereignty, Statehood and State Responsibility: Essays in Honour of James Crawford-and a book discussion-between Dr Russel Buchan, author of International Law and the Construction of the Liberal Peace, and Jessica Corsi-ensured that the Conference theme was explored from a variety of angles. The discussions continued over coffee breaks and during the Conference dinner, and we are pleased that a number of joint research projects have emerged from this exchange. Overall, the Conference attracted 150 participants.

The transnational and interdisciplinary focus of the Conference is reflected in the variety of analytical approaches and normative outlooks of the articles in this Issue, as well as in the spectrum of legal and geographical backgrounds of the authors. The following 12 articles were selected from the more than 40 papers presented at the Conference through a rigorous peer review process and the authors were given the chance to revise their papers for publication.

The Conference opened with the keynote address by Dame Rosalyn Higgins DBE QC, which has been reproduced in this Issue. In this contribution, Dame Rosalyn argues that we cannot think of democracy in an international context without taking into account human rights and the rule of law. She explores how this approach may help us define more clearly and better promote the concept of democracy at the international level. Judge Christopher Vajda's contribution to this Issue, also based on his keynote speech, examines the democratic legitimacy of the European Union's institutional structure and of its legislative and adjudicative processes. He refers to a number of recent judgments of the Court of Justice of the European Union to illustrate his arguments. The two keynote addresses constitute the first section of this Issue.

The second section of this Issue addresses democratic challenges in times of crisis in the European Union. Matej Avbelj identifies internal and external processes that affect democracy in the European Union. He makes a number of normative proposals embedded in the theory of constitutional pluralism. Antonia Baraggia examines the impact of conditionality measures to be implemented by money-borrowing countries on democratic governance, and the role of domestic supreme courts as watchdogs of democratic ideals in this context. Afroditi Ioanna Marketou argues that constitutional developments within crisis-hit countries merit closer attention than they have been given so far. She observes a 'loss of faith' in the Greek Constitution as a consequence of the financial crisis.

The third section of this Issue focuses on the promotion of democracy through international law and the interplay of democracy and the principle of self-determination. Russell Buchan proposes an explanatory framework that distinguishes between the international community, formed of liberal states, and the pluralist international society. By distinguishing between the group of liberal states and the group of non-liberal states, and by exploring their interaction, Buchan argues that we can better understand how and why conflicts in the international community occur, and how certain liberal values 
are promoted. Kalkidan N Obse and Christian Pippan illustrate the limits of the African Union's policy on constitutionalism and democratic governance in Africa in light of political realities. They suggest that the definition and application of the concept of 'unconstitutional changes of government' should be clarified. In Amichai Magen's view, the global decline in interest among states in the promotion of democracy is no longer hypothetical. He proposes that democratic rights are 'layered', and analyses the current status of these different democratic layers in the international legal order. Vladyslav Lanovoy looks at the operation of the right to self-determination outside of the context of decolonisation. He analyses the relationship between self-determination and democracy, with particular reference to Kosovo and Crimea.

The final section of this Issue is devoted to the diverse actors which can contribute to generating democratic norms outside of national parliaments and national executives. Silvia Suteu explores the role of citizen assembly-style constitutional conventions for the revitalisation of representative democratic institutions. She warns that they should not be advocated as a 'one size fits all solution' to the challenges of representative democracy. Anna Gamper distinguishes different types of law-making by constitutional courts from a comparative perspective, and critically appraises their democratic legitimacy. She assesses whether constitutional courts can compensate for the democratic deficit which she detects through their function as guardians of the constitution. Finally, Andreas Kulick discovers the intersections of international investment law and democratic governance. His contribution focuses on the role of the different actors in investment disputes, and points towards the potential limits of furthering democracy in this forum.

Without the help of the members of the Faculty of Law of the University of Cambridge, who so willingly offered their expertise and time, neither this Issue nor the Conference would have been possible. Many members of the Faculty supported the Conference by chairing its panels and reviewing papers. Professor Richard Fentiman, Chair of the Faculty Board, kindly agreed to open the Conference. Professor Christine Gray assisted greatly in securing one of the most outstanding conference venues in Cambridge-the Old Divinity School at St John's College. We would also like to thank Professor Kenneth Armstrong, Director of the Cambridge Centre for European Legal Studies, and Professor Marc Weller, Director of the Lauterpacht Centre for International Law, for their invaluable support. Special thanks are in order to Professor James Crawford, who has now become His Excellency Judge James Crawford, for his continued contribution to the success of the Journal.

We are also extremely grateful to our team of Conference Assistants, Massimo Lando, Michele Grassi and Jing Zhao, for their hard and diligent work. They committed much of their time in the course of this project to its eventual success. Emma Bickerstaffe provided thoughtful advice regarding the logistics of the Conference throughout our preparation for it. Special thanks are due to our Editors-in-Chief, Ana Júlia Maurício and Naomi Hart, who assisted in every way with the project at all of its stages. All members of the Editorial Board contributed to the preparation of this Issue for publication, and we are very grateful for this. 
We would also like to acknowledge the financial support of Hart Publishing, Cambridge University Press, the Cambridge Centre for European Legal Studies, the Lauterpacht Centre for International Law, the Cambridge Law Journal, and the Whewell Fund.

Finally, we are grateful to all those who attended and participated. 